\title{
EMPHASIZING THE CULTURAL AWARENESS IN TRANSLATION TEACHING
}

\author{
Roswani Siregar \\ Department of Economics, Universitas Al-Azhar, Medan - Indonesia \\ Corresponding author: roses_air@yahoo.com
}

\begin{abstract}
Language is a means of communication closely related to social and cultural values. Translation as an intelligent process is a human activity that bridging the cultures. However it is not always easy when translator encounter the culture-items. This paper provided short overview about the emphasizing of culture awareness in translation teaching. The participants are the students of Law and Economic Faculty of Universitas Al-Azhar, Medan, Indonesia. Throughout the classroom activities: theories, discussion, practicing and response to questionnaire, the students encouraging to aware the cultural influences in translation. To do so, they need more practice with culture specific items that related to their subjects. Students were motivated in learning translation when they involve in discussion and using internet as the comparable source. By emphasizing the importance of cultural awareness, the students impulse to learn more about other culture as well as improving their target language competence to avoid mistranslation.
\end{abstract}

Keywords: translation, teaching, culture, awareness

\section{Introduction}

Globalization is characterized by the growing number of connection that resulting in communication among people with different linguistic and cultural backgrounds. It takes place in the form of business, education and science, tourism, bilateral and multilateral government's cooperation, and also affected by immigration.

Human history recorded that translations have contributed greatly to information exchange across the cultural boundaries. Thus, translation is regarded as a tool for communication between diverse cultures and people of different backgrounds that enables people to send and to receive information and to maintain the ongoing and successful communication. Besides the differences in languages, there are also differences in cultures and people representing those differing cultures.

As James (2002) argues her Translation Journal article, the problems when translating text with cultural bound is sometimes not only purely lexical character but also of an equally fundamental nature such as a social, economic, political and cultural context as well as connotative aspects of a more semantic character. When it comes to 
translation teaching, the teacher should establish a good atmosphere to learn. Translation activities should be well-prepared. First of all, an appropriate text to be translated should be selected and must be interesting and relevant to the needs of the learner. Digilene (2012: 126) argues that the material to be translated is potential for encouraging discussion in classroom. In her preliminary study in designing translation course plan, Siregar (2017: 323) suggests that translation activities should create the desire for communication and encourage the students to be creative and contribute their ideas. The good learning atmosphere can be a nest for students to enjoy the translation class, especially about this topic. To do so, this paper will describe what translation is and how translation has a great deal with culture. In the part of discussion this paper will show the students culture awareness in translation practice.

\section{Literature Review}

\section{Language as carrier of culture}

Nobody doubts that language takes a crucial role in society. People express, share and transmit ideas with their corresponding cultures. Thus, culture and language are inseparably intertwined, just as Rivers (1981: 315) says "Language cannot be separated from the culture in which it is deeply embedded".

Any language can be regarded as a signal system that represents a particular culture. Bassnett (2004: 22) argues, language is the heart within the body of culture, and it is the interaction between the two that results in the continuation of life-energy. Thus, no language can exist out of the culture; and no culture can exist without embedded in the structure of the natural language.

Samovar, Porter and Stefani (2000: 36) define culture as the deposit of knowledge, experience, beliefs, values, actions, attitudes, meanings, hierarchies, religion, notions of time, roles, spatial relations, concepts of the universe, and artifacts acquired by a group of people in the course of generations through individual and group striving.

The closeness relation and intertwining of culture and language is done by way of symbols and rules as well as people's perceptions. Thus, it is impossible for any language absence from culture, as language is a set of symbols and the rules for combining those symbols that are used and understood by a community. When we study foreign language, the student will discover that not only are the symbols (words) and sounds for those symbols is different, but so are the grammar, syntax, phonology and intonation (rules) for using those symbols and sounds." (Samovar, Porter \& Stefani, 2000: 122)

Lotman and Uspensky in their book On the Semiotic Mechanism of Culture (1978: 211) say "no language can exist unless it is steeped in the context of culture; and no culture can exist which does not have at its centre, the structure of natural language".

\section{Translation and Culture}

Translation serves as an important means in cross-cultural communication in the human history. It bridges two different languages that are used to express what two 
communities think, do, and say. For Jeremy Munday (2001: 4-5) translation has several meanings. Translation can refer to the general subject field, the product which is known as translated text or the process that known as translating activity.

The closeness of language and culture is reflected in Larson (1984), she believes that one translates culture and not language arguing. Lefevere (2004) also argues that language is a part of culture, as well as the two languages structure. Lefevere claims that translation aims at influencing the development of a culture and the development of a literature.

Cultures are objectively different; thus, translation is to deal with cultural differences, promoting cultural exchange. Because of translation process is always regarded as bilingualism dealing, it inevitably involves biculturalism. Clearly, translating any language into another language involves two different cultures. Thus, the translators should cultivate the profound and comprehensive culture knowledge as well as the full familiarity with the language symbols so as to obtain the deep comprehension of the cultural differences (X He, 2012: 74).

The process of translation between two different written languages involves the translator changing an original written text (also called the source text) from the source language (SL) into a written text (target text) in a different verbal language (TL)."

It is necessary for teacher to teach about the target culture in translation classes so that students are not only taught how to meet their communicative goals, but also are taught the sociocultural knowledge of the second language group that is necessary in drawing inferences about the social meanings or values of utterances. (Canale in Fleet (2006: 8)

\section{Research Method}

Participants. This short course was conducted in a classroom setting who attended by 36 voluntary students from two faculties in Universitas Al-Azhar, Medan - Indonesia. The cluster random sampling technique is used in selecting sample.

Procedures. Teacher describe the purpose and benefit of short course for students. They also equipped with the background of translation and theory. In practicing translation, the students were motivated to discuss with others, raise the question, and dig the information from internet. In the end of class, students fill the questionnaire, and their response to classroom activities and discussion were recorded as source of data.

Materials. Teacher provides texts that suitable for both backgrounds. The text contains specific terms in economic, business, law and contracts. The general type of text is given in the first practice. After introducing the cultural influence on translation, the specific type of text is given for assignment. This type of text is the basis to draw the students' response on issue. 
Proceedings of the $1^{\text {st }}$ Annual International Conference on Language and Literature, 18-19 April 2018, Fakultas Sastra, UISU, Medan, Indonesia.

\section{Discussion}

\section{Promoting Culture into Classroom Teaching}

Classroom is a place in which both learner and teacher learn about things. It serves a space where learning can take place uninterrupted by outside distractions. Clark and Starr (in Moore, 1998: 6) suggest that teaching is an attempt to assist students in acquiring or changing some skill, knowledge, ideal, attitude, or appreciation. Thus, the effective teaching is central to the process of learning and teaching. In line with the culture, the teacher must first consider what culture knowledge to teach and how to integrate it into classroom teaching.

Students who are learning translation is prepared to be translators. They became as a cultural mediator, is destined to be equipped with cultural awareness. Thus, by translation teaching the foreign language teacher not only makes the students aware about the culture, but also promotes intercultural awareness.

In line with the purpose of this paper, the findings of this study show the cultural awareness of students in learning translation. The answer to questions reveals the cultural awareness of student in dealing with translation.

Table 1. Q1: Culture Awareness in Translation Process

\begin{tabular}{|l|c|c|c|}
\hline Question & Yes & No & Abstain \\
\hline Do you aware the culture influence in learning translation? & 19 & 11 & 6 \\
& $(53 \%)$ & $(30 \%)$ & $(17 \%)$ \\
\hline
\end{tabular}

Table 2. Q2: Term or phrase identified as cultural awareness

\begin{tabular}{|l|c|c|c|}
\hline Question & $\begin{array}{c}\text { Economic } \\
\text { Students }\end{array}$ & $\begin{array}{c}\text { Law } \\
\text { Students }\end{array}$ & Abstain \\
\hline $\begin{array}{l}\text { Can you specify the term and or phrase related to culture in } \\
\text { translation process? Show the passage contains it. }\end{array}$ & $\begin{array}{c}10 \\
(27 \%)\end{array}$ & $\begin{array}{c}6 \\
(16 \%)\end{array}$ & $\begin{array}{c}17 \\
(47 \%)\end{array}$ \\
\hline
\end{tabular}

The above questions are used to determine students' cultural awareness. Among the 36 students, the Q1 reveals 19 (53\%) students aware about the cultures in translation process, while 11 (30\%) unaware and, the rest are abstain.

The Q2 attempts to reveals how the student identified the culture influenced on text and translation process. In response to Q2, among 19 students who aware the culture in translation process, $10(27 \%)$ are students of Economic Faculty and6 $(16 \%)$ are students of Law Faculty. 3 of 19 students who express aware about the culture choose to abstain. Total abstain students who regarded as culture unaware in translation process are 17 (47\%).

Table 3. Student specific response to Q2

\begin{tabular}{|c|c|}
\hline Economic Text & Legal Text \\
\hline $\begin{array}{l}\text { Stamp duty } \rightarrow \text { Bea materai, pajak yang } \\
\text { dibayarkan pada saat membeli sebuah } \\
\text { properti. Stamp duty tertera dalam dokumen. } \\
\text { payable } \rightarrow \text { hutang } \\
\text { receivable } \rightarrow \text { piutang } \\
\text { bond } \rightarrow \text { obligasi }\end{array}$ & $\begin{array}{l}\text { in lieu of } \rightarrow \text { pengganti } \\
\text { Sale or return contracts often arise when a merchant } \\
\text { purchases goods primarily for resale, but in the right } \\
\text { to return part of all of the goods in lieu of payment if } \\
\text { the goods fail to be resold. } \\
\text { Hereinafter, henceforth, } \rightarrow \text { selanjutnya } \\
\text {... }\end{array}$ \\
\hline
\end{tabular}


For example: when students identify the terms stamp duty and in lieu of, they immediate looking for the meaning by search the corpus on internet. Some students showed the the origination of the term (Spain), and how it adopted in other cultures (Netherlands, France, Denmark, Prussia, and England and up today). While, in lieu of comes from Latin: locus meaning "place," or substitute of something. This term is commonly encountered in the phrase "in lieu of," that equals to "instead of". Thus by consider the cultural influence on these terms; students decided to avoid the literal translation.

\section{Q3: Teaching Cultural Awareness in Translation}

When teaching a culture specific item, the first language equivalent can also be given in order to enhance learning. The use of culture-based activities in the classroom will encourage students to be familiar with the target culture. Cakir (2006: 154).

By reviewing the finding on Q1 and Q2 and in dealing with the students who unaware of the culture in translation process, teacher brought the class to specific session. It is not always simple to get students into this point. In particular case, finding the equivalence word(s) in target language may opposite to native culture, and the importance of linguistically relevant information is sometimes neglected. For example:

Table 3.

\begin{tabular}{|l|l|}
\hline \multicolumn{1}{|c|}{ Indonesian Culture } & \multicolumn{1}{c|}{ Western Culture } \\
\hline Seputih kapas & As white as snow \\
\hline Ala bisa karena biasa & Practice makes perfect \\
\hline Bersakit-sakit dahulu bersenang-senang kemudian & No pain, no gain \\
\hline Tak ada rotan, akar pun jadi & A half loaf is better than none \\
\hline Siapa cepat dia dapat & Early bird catches the worm \\
\hline
\end{tabular}

Those expressions were provided as examples for students to aware of the cultural differences that influence the choice of words in translation. Thus, students are urged to pay more attention to these differences. They should think about the meaning carefully, and discover the corresponding expression in the target language.

As Q4 is given, the students are assigned to translate an English text into Indonesian, and mark out the terms and phrases or expressions that contain cultural differences. This attempt motivated the unaware students to do so.

Table 4. Q4 : Terms identification on Cultural Influence in Translation

\begin{tabular}{|c|c|c|}
\hline English & Indonesian & Category \\
\hline $\begin{array}{l}\text { over head } \\
\text { operator } \\
\text { check-up }\end{array}$ & $\begin{array}{l}\text { over head } \\
\text { operator } \\
\text { check-up }\end{array}$ & pure loanwords \\
\hline $\begin{array}{l}\text { qualification } \\
\text { penalty } \\
\text { priority } \\
\text { compensation } \\
\text { pay period } \\
\text { contract period } \\
\end{array}$ & $\begin{array}{l}\text { kualifikasi } \\
\text { penalti } \\
\text { prioritas } \\
\text { kompensasi } \\
\text { periode pembayaran } \\
\text { masa kontrak }\end{array}$ & mix-loanwords \\
\hline $\begin{array}{l}\text { legal fees } \\
\text { practice of dealing }\end{array}$ & $\begin{array}{l}\text { ongkos penasehat hukum } \\
\text { praktek-praktek transaksi }\end{array}$ & calque \\
\hline stamp duty & bea materai & transposition \\
\hline
\end{tabular}


Proceedings of the $1^{\text {st }}$ Annual International Conference on Language and Literature, 18-19 April 2018, Fakultas Sastra, UISU, Medan, Indonesia.

\begin{tabular}{|l|l|l|}
\hline income statement & laporan laba-rugi & \\
\hline meal allowance & uang makan & adaptation \\
legal fees & ongkos penasehat hukum & \\
allowances & biaya umum & \\
$\ldots . . .$. & $\ldots . . .$. & \\
\hline
\end{tabular}

The students result on this assignment revealed their recognizing in cultural-bound terms and phrase in translation process. The aware of cultural-bound terms impulse the student to learn more about the source-text cultures and field that suppose to lessen mistranslation and produces the acceptable translation.

\section{Conclusions}

From the point of view of translation theorists, translation takes place between two languages which are separately intrinsic parts of a culture, and which are both culturally-bound. Since translation is an intentional process that involved cultures within, thus the cultural awareness should should be emphasize in translation teaching. In practice, teacher may use various field of texts about cultural items. It is an effective way to broaden the students' insight into various cultures that improve their translation competency.

From our discussion so far, the cultural awareness can be an element in translation teaching inquiries. It is inseparable from language. Thus, in dealing with translation, the students should urge to pay more attention to cultural-items. Culture awareness is a useful tool in our daily life. It influences our views, values, hopes, even our worries and fears. Understanding cultures is a key to build the harmony and build strong relationships.

\section{References}

Bassnett, Susan. (2004). Translation Studies. Shanghai: Shanghai Foreign Language Education Press.

Cakir I. (2006). Developing Cultural Awareness in Foreign Language Teaching. Turkish Online Journal of Distance Education-TOJDE July2006. ISSN 1302-6488. Volume: 7 Number: 3. Retrieved from http://tojde.anadolu.edu.tr/ yonetim/icerik/makaleler/283-published.pdf

Canale, M. (1983). From communicative competence to communicative pedagogy. In J.C. Richards \& R.W. Schmidt (Eds.). Language and Communication (p. 2-27). London, England: Longman.

Fleet M. (2006). The Role of Culture in Second or Foreign Language Teaching: Moving Beyond the Classroom Experience. Culture Teaching 1. Retrieved from https://files.eric.ed.gov/fulltext/ED491716.pdf

He, Xuelin. (2012) Cultural Awareness and Translation Teaching at Higher Vocational College: Problems and Solutions. Journal of Language Teaching and Research, Vol.3, No.1, pp.74-83, January 2012. Retrieved from: http://www.academypublication.com/issues/past/jltr/vol03/01/09.pdf

I Dagilienè. (2012). Translation as a Learning Method in English Language Teaching. Studies About Languages. No. 21. Retrieved from http://www.kalbos.ktu.It/index.php/KStud/article/download/\%25201469 
James K. (2012). Cultural Implications for Translation. Translation Journal, Volume 6, No. 4 October 2002. Retrieved from http://translationjournal.net/ journal/22delight.htm

Larson, M. 1984. Meaning-Based Translation: A Guide to Cross-Language Equivalence. Lanham: University Press of America.

Lefevere, André. (Eds). (2004). Translation/History/Culture: A Sourcebook. Shanghai: Shanghai Foreign Language Education Press.

Lotman, J., Uspensky, B. (1978). On the Semiotic Mechanism of Culture, New Literary History, pp. 211-32.

Moore, Kenneth D. (1998). Classroom Teaching Skills (4th Edition). New York: McGraw.

Munday, Jeremy. (2001). Introducing Translation Studies: Theories and Applications. London and New York: Routledge.

Rivers, W.M. (1981). Teaching-Foreign Language Skills. Chicago: The University of Chicago .Press

Samovar, Larry A., Porter, \& Stefani. (2000). Communication Between Cultures (3rd edn.). Beijing: Foreign Language Teaching and Research Press.

Siregar R. (2017). Designing Course: An Initial Approach To Translation Teaching. International Journal of Scientific \& Technology Research, volume 6, Issue 09, September2017. ISSN 2277-8616. Retrieved from http://www.ijstr.org/final-print/sep2017/Designing-Course-An-InitialApproach-To-Translation-Teaching.pdf

Ulvydiene L. (2012). Psychology of Translation in Cross-Cultural Interaction. 3rd World Conference on Psychology, Counselling and Guidance (WCPCG-2012). 